\title{
Chapter 19 \\ Building Materials and Construction: Sustainability, Dependency and Foreign Suppliers
}

\author{
Frank Veraart
}

\section{Contents}

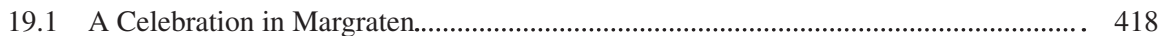

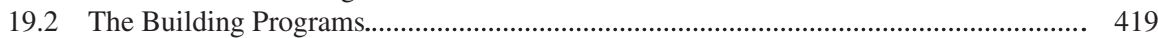

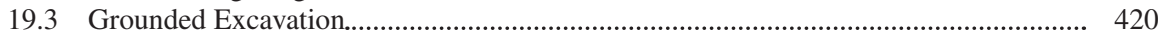

19.4 Passing the Buck or Market Forces................................................................................ 424

19.5 'Toward a Strategy for Raw Materials'....................................................................... 428

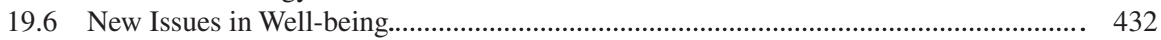

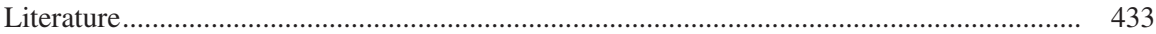

Abstract This chapter describes the extraction of mineral subsoil resources in a changing context of increasing internationalisation and domestic concern for nature and the environment. The cases are gravel and marl in the province of Limburg and the European inventory of strategic mineral resources. The period around 1970 formed the high point of Dutch building activities. The extraction and production of building materials had an increasing impact on the landscape (see Chap. 14). Bringing laws against excavations and spatial planning to bear, the government increased its control over the extraction activities. The new policy integrated the excavations in spatial planning and landscape goals.

The politicisation of environmental issues led to the harmonisation of the extraction of mineral resources with the local societal requirements for tourism, nature development, and flood control. Intensification of European cooperation positioned domestic extraction within a European economic framework. Higher prices for gravel and other building materials made recycling, among other things, attractive. The mining of gravel shifted in part to surrounding countries where it resulted in local damage to the landscape.

The outsourcing of gravel mining was similar to the overall European offshoring of the mining of mineral subsoil resources. From 2008 the European Commission commenced investigations into strategic mineral resources. The Netherlands followed in its footsteps. Initially, geological, economic and geo-political aspects were the main concerns. In a later phase, environmental issues and working conditions 
played a role. Developments in the area of well-being and sustainability required not only measures close to home, but also a concern for these issues outside of the Netherlands.

Keywords Mineral resources · Gravel · Offshoring · European Union · Metals

\subsection{A Celebration in Margraten}

Justified joy for many in Limburg yesterday after the unexpected decision by minister SmitKroes to spare the Margraten plateau. The years-long struggle by the people around and on this beautiful piece of Limburg, municipal officials, and environmentalists, has not been futile... ${ }^{1}$

Despite the potential loss of jobs, the government had rejected a request by the cement company ENCI to expand its operations. As the government explained to the Provincial Estates of Limburg: 'In 1992, in the framework of an emergent Europe, maintaining a national cement industry has declined in value.' ${ }^{2}$ The decision came as a surprise:

... Yesterday no one had much hope that the cabinet would arrive at this decision. A decision that does however resonate with the bow-wave of interest that has emerged recently at all levels for the improvement of our natural environment. An issue for which even employers and trade unions have fallen into each other's arms. On the Plateau of Margraten the environment has triumphed over industry...

Opinions about digging for mineral subsoil resources like marl, gravel and sand had shifted. Up to 1970, housing construction, the Delta works and other investments under the aegis of reconstruction had been the priorities steering the domestic production of cement and the mining of sand and gravel. After that time, landscape and environment also began to be incorporated into policy-making.

In the first part of this chapter we dwell upon the building programs from the 1970s on. What role did Dutch raw materials play? What factors were responsible for changing views on the domestic production of raw materials? In the second part of the chapter we illustrate these changes using gravel-mining as an example. Changing perspectives provided the impulse for developing a raw materials policy for construction materials.

But worries about mineral raw materials extended beyond marl, gravel, and sand. European assessments and unrest about Chinese policies led in 2010 to questions

\footnotetext{
1 'Eigen cementindustrie in open Europa niet nodig', in Limburgs Dagblad 19-01-1989, p 21

2 'Milieu wint het van economisch belang bij verbod tot afgraven mergelplateau' in NRC Handelsblad, 19-1-1989
} 
about the depletion and availability of copper, tin, indium and other metals. Once again the question was raised: what role did (mineral) raw materials play in the Dutch economy? What risks were there for Dutch industrial sectors? What policy was needed for economically vital raw materials? These last questions will be addressed in the concluding part of this chapter.

\subsection{The Building Programs}

Dutch building efforts experienced an apotheosis around 1970. On the basis of the 1966 Second Memorandum on Spatial Planning, that had predicted 20 million inhabitants by the year 2000, the volume of housing construction stood at an alltime high. In 1972 and 1973, 150,000 new dwellings per year were being realised. They were built above all in the outskirts of cities and in suburban 'growth cores.' ${ }^{3}$ A new national road plan - also published in 1966 - stimulated an increase in the construction of national roads, for the most part, limited access highways. 1966 also saw the publication of the Memorandum on Maritime Harbours, that envisioned the improvement of Rotterdam's Europoort harbour by means of landfills and its further extension into the sea in the form of the Maasvlakte. ${ }^{4}$ Coastal defences also acquired a significant boost from the ongoing Delta works.

The enormous pace of construction and the technocratic style of governance that made this possible became a focus of criticism around 1970. Social protest decrying the poor quality of life in cities and emerging worries about the environment turned against the planners and builders of cities, roads and dikes. The protest movement succeeded in convincing the political establishment. Plans were re-evaluated. The symbol of the turnaround became the storm-surge barrier in the Eastern Scheldt (the Oosterscheldekering) a marvel of technological prowess that replaced the planned total closure of the estuary, the Eastern Scheldt. This adjustable storm-surge barrier was completed in $1986 .^{5}$

Urban construction aimed at urban renewal and the compact city. In addition to investments in city centres, it included the construction of about 835,000 dwellings between 1995 and 2015 around nexuses of public transport in close proximity to the bigger cities. The plans also included investments in the 'mainports.' Rotterdam's harbour was to be expanded with a second Maasvlakte and its throughput capacity

\footnotetext{
${ }^{3}$ H. van der Cammen and L.A. de Klerk, Ruimtelijke Ordening, van Plannen Komen Plannen, de Ontwikkelingsgang van de Ruimtelijke Ordening in Nederland, 4e ed. (Utrecht: Het Spectrum, 1999), 147.

${ }^{4}$ Han Meyer, De Staat van de Delta, Waterwerken, Stadsontwikkeling en Natievorming in Nederland (Nijmegen: Van Tilt, 2016), 129-32.

${ }^{5}$ A. Bosch and W. van der Ham, Twee Eeuwen, Rijkswaterstaat 1798-2015, 2e druk (Asten: Nieuwe Uitgevers, 2015), 261-65.
} 
augmented with the Betuwe route, a freight railway line to the German hinterland. Schiphol Airport would get a fifth runway and would be made accessible for highspeed trains. ${ }^{6}$

Perilously high river stages on the Meuse and Rhine in 1993 and 1995 were an incitement to reassess flood risks in the region of the large rivers. In 1995 portions of cities along the Meuse were flooded and 250,000 people were evacuated from the river-region of the province of Gelderland. These crises eventuated in the Delta Plan for the Big Rivers, an accelerated program of levee reinforcements in the river region. At the same time more attention was devoted to the expected effects of climate change, in particular increasing rainfall and sea-level rise. These new insights took shape in the 'Room for the River' program that was implemented between 2005 and 2015. In this program engineers combined the creation of hydraulic infrastructures with environmental policy, landscape development, and spatial planning.

The new political preferences of a conservative national government became visible in 2004 in proposals contained in the so-called Space Memorandum (Nota Ruimte). This memorandum brought together different spatial planning domains like transport, nature, agriculture, industry and urban development. However, their coordination was transferred from the national to lower levels of government. The national government was to restrict itself to the delineation of overall structure and core regions in line with European directives.

Sensitivity to climate change and sea-level rise led to increased concern for the coast. A survey held in 2003 revealed that more than $40 \%$ of the primary coastal defences did not yet satisfy the Delta norms established in 1961. The 'weak links' along the coast were dealt with after 2006. At various locations the coast was reinforced by sand suppletion in a manner that conserved the ecological and recreational values of the dune landscape. In 2007 the government appointed a new Delta Commission. This analysed the consequences of sea-level rise for the Netherlands and recommended possible countermeasures. In 2009, the Commission's recommendations led to the financing of this sustainability agenda and to a first 'National Water Plan' that would guarantee not only defences against water but also the supply of fresh water. The plan, to be revised every 6 years, ongoingly establishes the norms and the implementation program. ${ }^{7}$

\subsection{Grounded Excavation}

Sand, gravel, and chalk (including marl) were the most voluminous building materials. Domestic mining of gravel and marl had been concentrated since the midtwentieth century in the province of Limburg (see also Chap. 14). The mining of

\footnotetext{
${ }^{6}$ Nil Disco and Frank Veraart, 'A Farewell to Big Planning? 1990-2010,' in Builders and Planners, a History of Land-Use and Infrastructure Planning in the Netherlands, ed. Jos Arts et al. (Delft: Eburon, 2016), 361-77.

${ }^{7}$ Meyer, De Staat van de Delta, Waterwerken, Stadsontwikkeling En Natievorming in Nederland, $150-82$.
} 
these kinds of shallow subsoil resources had been regulated since the 1960s in the Excavation Law. New excavation permits thus became embedded in regional structure plans, that also regulated activities like recreation and nature conservation. Digging for shallow subsoil resources thus became increasingly constrained.

In 1974 the Federation of Shallow Subsoil Resource Extraction Industries (FODI) sounded the alarm. It warned that if a conservative excavation policy were maintained it would not be possible to guarantee materials supplies for the building industry, including the public works sector. ${ }^{8}$ In response, the Ministry of Transport and Public Works launched an investigation into the demand for raw materials. After 1976 a National Commission for the Coordination of Excavation Policy (LCCO), composed of representatives of the Ministry and the provincial estates, was charged with harmonizing the demand for and the supply of shallow subsoil resources. The LCCO developed 'target plans' for the different provinces in the form of 10-year plans. The first of these 'target plans' appeared in 1978.

The establishment of the LCCO was seen as the first step toward a national excavation policy. The environmental movement also began to take part in the discussion. The Foundation for Nature and Environment presented its own ideas for excavation policy. It pointed to alternatives such as the use of demolition waste, dredging mud, and slag from furnaces. They also pointed to alternative mining sites at sea, an increase in imports and they argued that because of its spatial implications excavation policy should be part and parcel of spatial planning policy. ${ }^{9}$ The 1966 Second Memorandum on Spatial Planning, after all, sketched the rough contours of land use, with specific attention to space for recreation and nature (see also Chap. 15).

Against this background, in 1976 the cement industry ENCI developed plans for extending the extraction of marl beyond 1991. Its existing concession on the Sint Pietersberg appeared to have reached its economic limits. This is why the firm now set its sights on extraction on the Margraten Plateau. This option, once rejected in the 1940s, now seemed the economically most opportune. The opposition, however, was fierce. No less than 8000 persons filed objections, in addition to the mayors of the affected villages and the chief superintendent of the Margraten American War Cemetery, who added an unexpected diplomatic loading to the controversy. Succumbing to popular pressure, the Limburg provincial estates postponed a decision on the procedures. ENCI as well as FODI protested and took the matter to court. In 1978 the Council of State, the nation's highest administrative court of appeal, ruled in their favour.

The subsequent renewal of the planning procedures was once again followed by mass protests and by a legal war of attrition involving objections and delaying tactics. Opponents also produced alternative plans and reports. Investigations into other extraction methods and excavation sites were again undertaken. Expectations of shrinking domestic cement production and new production processes involving

\footnotetext{
${ }^{8}$ G.J.A. Sigmond et al., 1974-1984, Tien Jaar: Industrie en Ontgrondingen (De Steeg, 1984).

${ }^{9}$ G.W. Grondelle, Ontgrondingen, over de Noodzaak en Mogelijkheden voor een Ander Beleid t.a.v. de Winning van Mergel, Grind, Zand, Klei, Veen, etc. ('s Gravenland: Stichting Natuur en Milieu, 1978).
} 
fly ash decreased the need for marl. This made further digging at the existing pit a feasible short-term alternative. In 1985 the Council of State ruled that in the context of these developments, ENCI could not, for the time being, start digging on the Margraten Plateau. The Province granted a permit to mine the Sint Pietersberg until 2010. This seemed to guarantee an adequate level of cement production for the coming 20 years. This compromise satisfied both opponents and proponents of marl mining on the Margraten Plateau. The peace, however, was of short duration. ${ }^{10}$

A new government memorandum - titled Grounded Excavation (Gegrond Ontgronden) - explored the long-term state of the national raw materials supply. The draft version that appeared in 1987 once again named the Margraten Plateau as a potential mining site. This led to a resurgence of the mass protests. In 1989 mayor Herman Kaiser of Margraten succeeded in enticing the Minister of Transport and Public Works, Neelie Smit-Kroes, to visit the targeted area. The visit was accompanied by a massive peaceful protest and led to the remarkable decision with which this chapter began. Two weeks after the visit the mayor received a phone call from the minister who said: 'you may keep your plateau.' The importance of a domestic cement industry was struck from the text of the definitive version of the memorandum 'Grounded Excavation.' The minister framed cement production in the context of European developments. This would eventually lead to the termination of marl mining.

The publication of the draft version of 'Grounded Excavation' also served as a starting point for negotiations with the various provinces regarding the 'targets' for the supply of shallow subsoil-resources. The Limburg provincial estates succeeded in reaching an agreement about limiting the mining of gravel. Another 80 million tons of gravel would be extracted in Limburg, enough to supply the estimated need for the 1990s and possibly somewhat longer. The new policy assumed that after the turn of the century, demand could be satisfied with alternative materials, mining at sea and imports. ${ }^{11}$ Re-use of building materials was also an option.

Re-use of building materials was stimulated by various environmental measures taken in consequence of, among other things, the Waste Materials Law (Afvalstoffenwet) of 1978. In the course of the parliamentary debates on this law, the Christian Democratic parliamentarian A.G.W.J. Lansink introduced the socalled Waste Hierarchy, a desirable sequence in dealing with waste materials: prevention of waste, re-use of 'waste' flows in production, transformation into energy and as final option controlled dumping of non-processable waste. ${ }^{12}$ This approach,

\footnotetext{
${ }^{10}$ Thomas Rode, ENCI's Struggle for the Margraten Plateau, a Clash of Economical and Environmental Interests (Maastricht University, Faculty of Cultural Sciences, Bachelor's Thesis, December 6, 2009), www.oudsintpieter.com/Presentaties.htm; Thomas Rode, 'Een Wereld van Cement? De Strijd Om Het Plateau van Margraten, 1976-1989,' Studies over de SociaalEconomische Geschiedenis van Limburg 55 (2010): 26-48.

${ }^{11}$ Paul Ike, De Planning van Ontgrondingen (Rijksuniversiteit Groningen, Geo Pers, 2000), 43-44.; B. De Jong, 'Ontgronden in Nederland een steeds groter probleem', in De Ingenieur, nr 11 (november 1989), p. 7-11.

${ }^{12}$ Tweede Kamer der Staten Generaal, Zitting 1979-1980, Rijksbegroting voor het jaar 1980, 15,800 Hoofdstuk XVII, Departement van Volksgezondheid en Milieuhygiëne, nr. 21, 'Motie van het lid Lansink c.s.', voorgesteld 1 november 1979.
} 


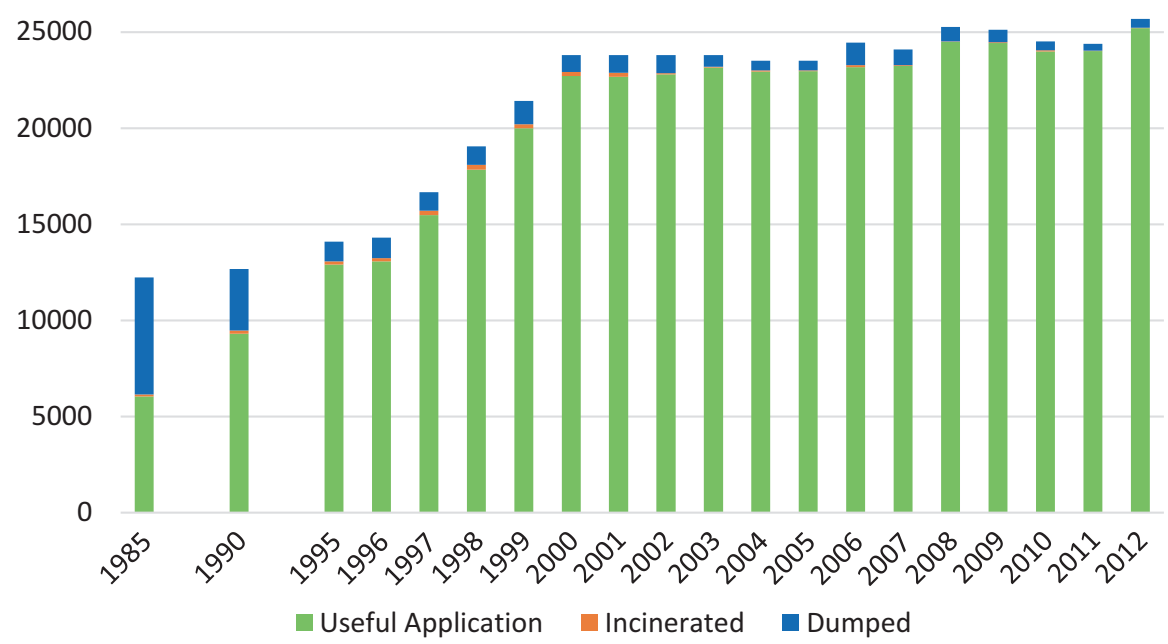

Graph 19.1 Available construction and demolition waste 1985-2012 (million kg) Source: Compendium voor de leefomgeving

that became known in the Netherlands by the name 'the Ladder of Lansink' became more nuanced in subsequent years. The first National Environmental Policy Plan (NMP) published in 1989 committed itself to reducing waste flows by employing so-called integral chain management. Industries were challenged to think through the environmental consequences of supplies, production, consumption and waste processing. This was supported by supplementary measures.

In the building sector, the emphasis was on the re-use of construction and demolition waste. Research at TNO and universities inventoried possibilities for re-use of waste in concrete, asphalt and foundation materials. In addition, new designs were promoted that needed fewer materials. ${ }^{13}$ The private sector played a big role in these activities. It was therefore hardly surprising that initiatives started with the re-use of demolition waste and not with prevention of use by re-using buildings. Prevention was the economically less attractive option.

Ministries, the building industries, and knowledge institutes worked together on preparing the so-called Building Materials Decision (Bouwstoffenbesluit) that was enacted in 1995. This stipulated the possibilities, norms, and rules for re-use. ${ }^{14}$ In that year, too, a prohibition against the dumping of re-usable building materials came into force. This stimulated an enormous increase in the re-use of construction and demolition wastes. In 1985 half of the wastes were re-used; after the turn of the century this increased to $97 \%$ (see Graph 19.1). In surveys of supplies of construction and demolition waste granulates it was proudly announced that, after Hong

\footnotetext{
${ }^{13}$ Jacqueline Cramer, Milieu, Elementaire Deeltjes 16 (Amsterdam: Amsterdam University Press, 2014), 35-48.

${ }^{14}$ R.T. Eikelboom, E. Ruwiel, and J.J.J.M. Gouwmans, 'The Building Material Decree: An Example of a Dutch Regulation Based on the Potential Impact of Materials on the Environment,' Waste Management 21 (2001): 295-302.
} 
Kong, the Netherlands was the frontrunner in the use of these recycled raw materials. ${ }^{15}$ Despite these achievements, critical voices were also heard. Re-use appeared above all to be so-called 'down-cycling.' Construction and demolition wastes served as fill material and as granulate for road foundations. In the use of concrete the primary raw materials still prevailed. ${ }^{16}$ For the time being this meant a continued significant need for gravel and masonry sand.

Regulations in the area of waste management and industrial developments in the area of integral supply chain management provided the basis for a policy program launched in 2013, 'From Waste to Raw Material.' These were the first steps on the road to a transition, embraced by the government and environmental organisations, toward a circular economy. ${ }^{17}$

\subsection{Passing the Buck or Market Forces}

In 2002 a commission under the chairmanship of the former state secretary for Public Housing, Spatial Planning and Environmental Policy (VROM) D.K.J. Tommel, formulated policy recommendations for the Structure Scheme for Shallow Subsoil Resources. The commission, entirely in line with the political climate of the time, recommended more leeway for market forces and less central steering by the state. The freshly elected Balkenende cabinet enthusiastically embraced the recommendations. The planning and coordination of shallow subsoil resources would no longer be a task for the government. Aspects of excavation policy, just like other spatial planning issues, were subsumed in the Space Memorandum of 2004. This memorandum expressed the new direction of policy. Government regulation was to be transformed into over-all planning. 'Decentralize where possible, centralize where necessary' became the new slogan according to which the state shifted responsibilities for spatial planning to the provinces and municipalities.

For excavation policy, this meant the gradual abandonment of coordination via targets and the liberation of market forces. The new policy underscored the importance of local extraction in order to prevent the displacement of environmental problems, needless transport, and excessive energy consumption. Policy aimed at so-called 'multifunctional' extraction, that united extractive imperatives with local needs.

It is expected of the excavating industry that it will orient itself to the development of qualitatively good and societally responsible projects in close cooperation with the affected parties. (...) This means that in the course of extraction use must be made of the chances offered by excavations for the realisation of other desirable social functions like nature

\footnotetext{
${ }^{15}$ U. Hofstra et al., Scenariostudie BSA-Granulaten, Aanbod en Afzet van 2005 Tot 2025 (Sittard: INTRON / Expertisecentrum Bouwstoffen Rijkswaterstaat, 2006), 15.

${ }^{16}$ Evert Mulder, Kringbouw, naar een Duurzame Grondstoffenvoorziening in de Bouw (Apeldoorn: TNO Industrie en Techniek, 2008)., p. 36-37.

${ }^{17}$ Cramer, Milieu, 91.
} 


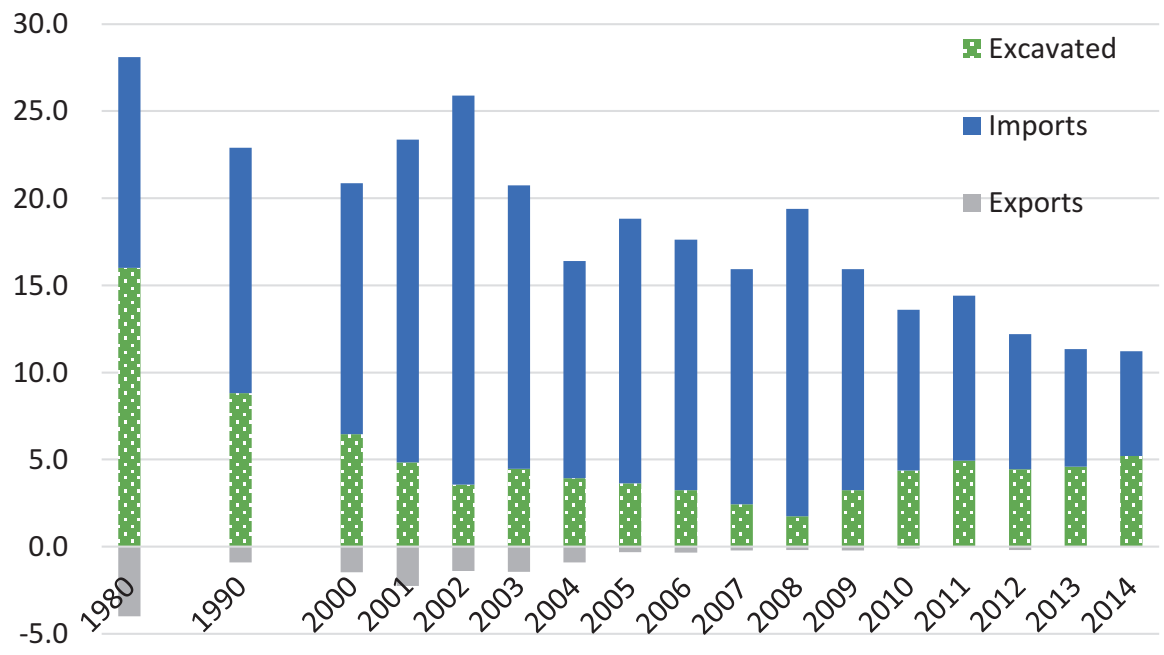

Graph 19.2 Excavation, import, and export of gravel 1980-2011 (million tons) Source: Rijkswaterstaat, Waterdienst en Compendium voor de leefomgeving (2000-2014)

development, recreation, waterfront residences, water management, the dredging of shipping channels. In this way projects can be realised that improve spatial quality and that provide the Netherlands with raw materials. ${ }^{18}$

This policy shift put an end to the promised reduction in gravel extraction. In Limburg the news was followed with eagle-eyes. In 2009, Limburg's newspapers headlined: 'Dredgers return' and 'Open door for gravel mining. ${ }^{19}$ Nature conservation organisations took a more positive view of the news. They were of course already struggling with the right-populist policies of the first Rutte cabinet. Budgets for nature development projects had been cut by $70 \%$, environmental regulations relaxed and elements of the European Natura 2000 network were postponed or terminated. ${ }^{20}$ Multi-functional gravel mining offered unexpected chances for nature development. The former opponents, dredging companies and nature conservationists, became new partners in the creation of wet nature development projects. ${ }^{21}$

As a rule, the additional demands placed on gravel and sand extraction led to price increases, to a decline in domestic production, and increasing imports of sand and gravel, particularly from Germany (see Graph 19.2 and Fig. 19.1). Germany

\footnotetext{
${ }^{18}$ Ministries of VROM, LNV VenW en EZ, Nota Ruimte, ruimte voor ontwikkeling, deel 4: text after parliamentary consent, Den Haag 2006, p. 165.

${ }^{19}$ Cited in Bert Hammes and Jan Hensels 'Baggermolen keert terug' in Dagblad de Limburger, October 5th 2009; Bert Hammes en Jan Hensels, 'Deur open voor ontgrindingen' in Dagblad de Limburger October 5th 2009; Bert Hammes en Jan Hensels, 'Grind roept emoties op' in Dagblad de Limburger October 9th 2009.

${ }^{20}$ Arjen Buijs, Thomas Matthijssen, and Bas Arts, "The Man, the Administration and the CounterDiscourse:' An Analysis of the Sudden Turn in Dutch Natures Conservation Policy,' Land Use Policy 38 (2014): 676-84.

${ }^{21}$ Sander Heijne, 'Struinnatuur in ruil voor grind', in De Volkskrant, August 10, 2011, p. 18.
} 


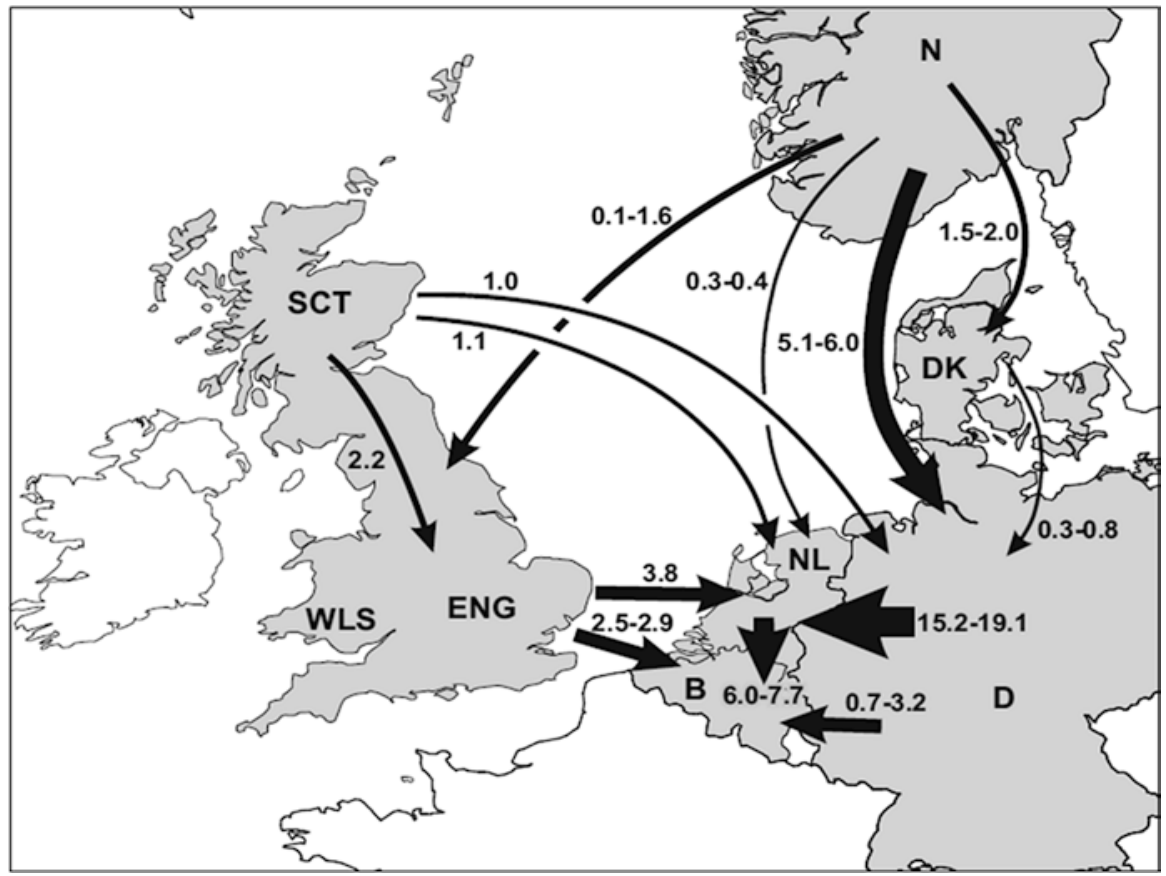

Fig. 19.1 Net flows of trade in sand, gravel and crushed stone among the countries around the North Sea

Source: M.J. van der Meulen, T.P.F. Koopmans, and H.S. Pietersen, "Construction Raw Materials Policy and Supply Practices in Northwestern Europe," Aardrijkskundige Mededelingen, Industrial Minerals - Resources, Characteristics and Applications., 13 (2003): 19-30

was not pleased. The Netherlands was simply transferring its sustainability problems to a neighbouring country. But the Tommel Commission redefined the problem. German irritation about Dutch policy shifts was seen as an indirect encouragement for Dutch policy:

The commission views resistance in Germany as a positive development for Dutch policy. Whereas in the Netherlands there seems to be a consensus that we want to work toward the development of qualitatively good and socially responsible excavation projects, in Germany the debate about goals is still in full swing. The commission expects that in the long run, due to social pressure, more demands will be made on projects, which will ultimately lead to a decline in the acquisition of cheap sand and gravel from Germany. (...) A possible price increase will, in point of fact, provide new possibilities for multi-functional projects and the utilisation of secondary raw materials. ${ }^{22}$

\footnotetext{
${ }^{22}$ D.K.J. Tommel, G. Blom, and M.A. van Weel, eds., Slotadvies van de Commissie Taakstellingen en Flankerende Beleid Voor Beton- en Metselzandvoorziening (Ministerie van Verkeer en Waterstaat, Interprovinciaal Overleg (IPO), December 17, 2009), 18.
} 
The phasing out of a directive role for the national government was concluded in 2012 with a parliamentary debate. In regard to the diplomatic pressure from Germany, Minister M.H. Schulz van Haegen (Infrastructure and Environment) wrote:

Via diplomatic channels, the cabinet has received signals from the government of NordrheinWestfalen that it is not happy with this. The Netherlands does not unnecessarily want to burden its neighbours with the spatial demands of raw materials acquisition (...) I share the expectations of the Tommel Commission that new projects have the potential to replace a substantial share of these imports. But this is dependent on market and price developments and on the demands that are imposed in Germany on the execution of sand mining projects and on the processing after extraction..$^{23}$

In the eyes of the Dutch government, increasing German exports to the Netherlands were the result of a free market. The lack of German sustainability measures made its shallow subsoil-resources attractive for the Dutch market. The remarks could be read as a covert bit of advice to German politicians. The Dutch government was not averse to more stringent demands and higher prices. It reasoned that these provided more possibilities for recycling and for more expensive multi-functional excavation.

The so-called 'structure schemes' for the shallow sub-soil resources with their estimates of demand and agreements about levels of supply were unique for the Netherlands. In contrast to surrounding countries, these kinds of strategic explorations were unusual in the Netherlands. ${ }^{24}$ After the turn of the century, the Dutch government traded in its national perspective on mineral raw materials for a broader European perspective. Research undertaken at the behest of the European Commission revealed that the Netherlands was the largest net importer of mineral shallow sub-soil resources (see also Fig. 19.1). ${ }^{25}$ In 1910, the top layer of Dutch roads consisted of asphalt made with Belgian and Scottish crushed rocks. Concrete was to a significant degree composed of gravel from Germany. By contrast, the foundations of buildings and constructions consisted primarily of domestic construction and demolition waste.

\footnotetext{
${ }^{23}$ M.H. Schultz van Haegen (minister of infrastructure and environment), in letter to parliament 'Slotrapportage afbouw rijksregierol bij ontgrondingen', March 5th 2012, p. 7. Kamerstukken 2012.

${ }^{24}$ Environmental historian Henk van Zon mentions among other things strategic surveys of coal in Germany and Great Britain from the eighteenth to the twentieth centuries. See Henk van Zon, Geschiedenis en Duurzame Ontwikkeling, Duurzame Ontwikkeling in Historisch Perspectief, Enkele Verkenningen, Vakreview (Nijmegen: Universitair Centrum Milieuwetenschappen, 2002), 36-53.; Another unique exception is the dispute around the zinc mine in Kelmis that in the course of the determination of the boundaries of the Kingdom of the Netherlands in 1820 led to a neutral territory administered jointly by The Netherlands (and after 1830 Belgium) and Prussia.

${ }^{25}$ M.J. van der Meulen, T.P.F. Koopmans, and H.S. Pietersen, 'Construction Raw Materials Policy and Supply Practices in Northwestern Europe,' Aardrijkskundige Mededelingen, Industrial Minerals - Resources, Characteristics and Applications., 13 (2003): 19-30.
} 
After the turn of the century, local judgements about environment, economy and spatial planning determined the development of the national mining of raw materials. Despite the existence of large quantities of sand, gravel, and marl, the domestic mining of mineral raw materials languished. The Netherlands trusted to international trade for its supplies of raw materials. But the question was what the limits and risks were of this outsourcing of raw materials supplies.

\section{5 'Toward a Strategy for Raw Materials'}

This question began to nag in 2008, but at an international European level. The European Union (EU) had become increasingly dependent on countries outside the Union for its raw materials:

On the one hand, the EU has many raw material deposits. However, their exploration and extraction are facing increased competition for different land uses and a highly regulated environment, as well as technological limitations in access to mineral deposits. On the other hand, the EU is highly dependent on imports of strategically important raw materials which are increasingly affected by market distortions. In the case of high-tech metals, this dependence can even be considered critical in view of their economic value and high supply risks. ${ }^{26}$

European leaders saw access to raw materials as strategic and necessary prerequisites for remaining competitive and for economic growth and jobs. The coming of specialised high-tech industry and services from the 1980s on had altered the material basis of the economy. On the one hand this mitigated the growth of material flows, while on the other hand ever higher demands were placed on exotic material properties and on purity. Scarce materials were the basis of a number of specific specialised applications. Rare molybdenum (Mo) for example, was used in the production of steel alloys for the chemical, the offshore and the automobile industries. Antimony, also rare, was applied in fire arresting compounds, in catalysts for plastics and in batteries. ${ }^{27}$

Materials scarcity proceeds from various causes. A number of these materials are geologically rare. In addition, mining plays an important role. Supply and demand are co-determinants of the scale of mining. Economically viable mining depends on the required purity and other effort required in the course of mining and purification. Economic profitability is varies with minerals that are by-products of other mineral

\footnotetext{
26 "The Raw Materials Initiative - Meeting our Critical Needs for Growth and Jobs in Europe," Communications from the Commission to the European Parliament and Council COM (2008) 699 (Brussels: Commission of the European Communities, April 11, 2008), 2.

${ }^{27}$ Th. Henckens, Managing Raw Materials Scarcity, Safeguarding the Availability of Geologically Scarce Mineral Resources for Future Generations (Universiteit Utrecht, 2016)., 74-79 and $110-112$.
} 
extraction. Due to all these factors, the debate concerning the degree of scarcity and depletion of materials is often left undecided. ${ }^{28}$

At the outset of the 1970s the Club of Rome had already put the issue of the depletion of raw materials squarely on the global agenda. After that, at least for mineral raw materials, the debate receded into the background. At the beginning of this century the issue received renewed attention in political circles. In November 2008 the European Commission launched the Raw Materials Initiative. A year later a European working group showed how immensely vulnerable Europe was in regard to imports of raw materials. These imports were a result of changes in international market relations due to the concentration of extraction in specific regions. This geographic concentration was not simply a geological phenomenon. Social pressure had shifted mineral extraction in Europe to other continents.

The analyses acquired increased importance because of the imposition of a quota on the extraction of rare earth metals by the Chinese government in 2009. An expected shortage of materials that threatened the production of mobile phones, flatscreen TVs, hybrid automobiles, solar panels and other developments in communications technology and sustainability, rapidly became world news. ${ }^{29}$

In 2010 the European Ad Hoc Working Group on Defining Critical Raw Materials presented the first results. It identified a group of 41 economically important minerals, of which 14 were potentially risky. The 'rare earths' and the platinum group metals (PGM) were risky due to quasi-monopolies by respectively China and Russia; the transition metals Tungsten and Niobium - much used in the fabrication of stainless steel - due to the enormous economic impacts. ${ }^{30}$

In response to the European investigation, the Dutch government requested Statistics Netherlands and TNO (the National Applied Science Research Institute) to do a study of materials crucial for the Dutch economy. The first results were reassuring. Direct use of the 41 'European' minerals was relevant for only a small fraction of the Dutch economy and the economy had no great degree of direct dependence on the 14 most crucial materials. ${ }^{31}$

But subsequent analyses of the production chains revealed a much greater dependency. Critical materials were used as raw materials in only $7 \%$ of production processes. These raw materials were much more often worked into metals (52\%) or as

\footnotetext{
${ }^{28} \mathrm{~A}$ pessimistic current among scientists assumes depletion; more optimistic scientists stress that higher prices will lead to the discovery of new mining locations and that technological developments will lead to the adoption of alternative materials. Ibid. 16-18.

${ }^{29}$ Piet Depuydt, 'Chinezen beheersen de zeldzame aardmetalen: Tekort aan onmisbare grondstoffen zet verhouding in de wereld op scherp', in NRC, sectie economie, 16-1-2010, p. 13.

${ }^{30}$ Critical Raw Materials for the EU, Report of the Ad-Hoc Working Group on Defining Critical Raw Materials (Brussels: European Commission, Enterprise and Industry, 2010).

${ }^{31}$ Critical Materials in the Dutch Economy, Preliminary Results (The Hague / Heerlen: CBS Center for Policy Related Statistics, 2010).
} 
Table 19.1 Share of the critical raw materials Indium, Neodymium en Copper in the Dutch economy in 2011

\begin{tabular}{|c|c|c|c|c|}
\hline & & Indium & Neodymium & Copper \\
\hline Import of goods & Million EUR & 20,914 & 553 & 33,809 \\
\hline Re-exports & Million EUR & 15,686 & 343 & 22,314 \\
\hline Exports & Million EUR & 26,902 & 555 & 36,008 \\
\hline Domestic imports & Million EUR & 5229 & 210 & 11,495 \\
\hline Domestic export & Million EUR & 11,217 & 212 & 13,694 \\
\hline \multicolumn{5}{|l|}{ Domestic use: } \\
\hline Consumption & $\%$ & 15 & 19 & 12 \\
\hline Investments & $\%$ & 39 & 8 & 22 \\
\hline Intermediate use by industry & $\%$ & 46 & 73 & 66 \\
\hline Total domestic imports & $\%$ & 100 & 100 & 100 \\
\hline Added value & Million EUR & 938 & 268 & 2889 \\
\hline As \% gdp & $\%$ & 0.2 & 0.1 & 0.6 \\
\hline Jobs & $\times 1000$ & 22.3 & 7.3 & 70.4 \\
\hline Jobs $\%$ of Dutch Total & $\%$ & 0.3 & 0.1 & 0.9 \\
\hline Import value Total NL & Million EUR & 375,393 & & \\
\hline Export value Total NL & Million EUR & 398,757 & & \\
\hline Total gdp & Million EUR & 513,525 & & \\
\hline Jobs (LISA) NL & $\times 1000$ & 7976 & & \\
\hline
\end{tabular}

Source: Korteweg (2011) p. 92

intermediate products (37\%). ${ }^{32}$ A so-called 'quick scan' analysed the material flows of Indium, Neodymium and Copper for the Dutch economy. ${ }^{33}$ Indium was applied in solar panels and LEDs. Neodymium was imported into the Netherlands chiefly as an ingredient of permanent magnets, used in windmills because of their low maintenance demands. The use of Neodymium had an added value of 268 million euros and was related to 7300 jobs. The impact of Indium at 938 million euros and 22,700 jobs, was even greater (see Table 19.1). The report showed the impact these specific materials had in the Dutch economy. But the report did not commence with the economic interpretation, but with geopolitical concerns.

The West no longer determines international trade and the political and economic balance of power has shifted in favour of emerging economies like China, India and Brazil.

The report pointed out the increasing popularity of state capitalism, with China as an example. The new 'multi-polar' relationships in the world were characterised by instability and ad hoc relations. The increased complexity might possibly lead to

\footnotetext{
${ }^{32}$ Derk Bol and Ton Bastein, Critical Materials and the Netherlands - a View from the IndustrialTechnological Sector (Delft: M2i Materials Innovations Institute / TNO, 2012), 5.

${ }^{33}$ Rem Korteweg, Op Weg Naar een Grondstoffenstrategie, Quick Scan ten behoeve van de Grondstoffennotitie (The Hague: The Hague Centre for Strategic Studies / TNO / CE Delft, 2011).
} 
friction among countries. The scarcity of raw materials could become one of the most important bones of contention.

The report speculated on chances for the Netherlands in the areas of recycling, pre- and post-consumption. Much might be gained by applying supply chain approaches and 'cradle-to-cradle' principles to the flows of critical materials. And according to the report critical materials could also play a role in development aid. 'The raw materials sector, if well-organised, is a catalyst for economic growth in African countries. ${ }^{34}$ How and if these recommendations were entangled, was not made clear. The 'quick scan' seemed above all to be a pragmatic summing up of opportunities.

The reports were the most important source of inspiration for the raw materials memorandum that was presented to parliament in 2011 by no less than four government ministries. In the multi-polar world 'security regarding the supply of raw materials had also for the Netherlands to a certain extent become an economic and safety concern.' According to the politicians, it would be obligatory to interfere with the market if that proved necessary. But the scarcity of raw materials also offered possibilities, like urban mining. Waste should be seen as a raw material and it would be necessary to invest in so-called raw-materials roundabouts. The memorandum also noted that sustainable extraction and processing of raw materials also offered opportunities for development aid..$^{35}$

New research by TNO into materials in the Dutch economy proposed another addition to the three familiar vulnerabilities. In addition to the geological-economic risks (reserves and production), ${ }^{36}$ the geo-political risks (stability of nations), and price fluctuations, TNO also pointed to the reputational damage for firms in the use of materials. A number of critical materials were appropriated with little respect for the environment or norms for well-being. This could possibly lead to reputational damage for companies that applied these materials. Suppliers to the transport equipment industry ran the greatest risk, according to TNO. This was due to their use of gold, tantalum, and tin, the mining of which in African countries was controversial. ${ }^{37}$ With this last point the report made visible the impact of economic activities on well-being and the environment elsewhere in the world. Well-being was not only a concern for governments, but also a strategic factor for companies.

\footnotetext{
${ }^{34}$ Rem Korteweg, Op Weg Naar een Grondstoffenstrategie, Quick Scan ten behoeve van de Grondstoffennotitie (The Hague: The Hague Centre for Strategic Studies / TNO / CE Delft, 2011).

35 'Grondstoffennotitie' aangeboden aan de Tweede Kamer op 15 juli 2011 door de ministers van Buitenlandse Zaken, Economische Zaken, Landbouw \& Innovatie en staatsecretarissen van Infrastructuur \& Milieu en Buitenlandse Zaken.

${ }^{36} \mathrm{~A}$ recent dissertation pointed to the development of 'absolute' scarcity and to the depletion in the short term of a number of metals like antimony ( 20 year supply), gold (40 years), zinc ( 80 years) and molybdenum (80 years). Henckens, Managing Raw Materials Scarcity.

${ }^{37}$ Ton Bastein and Elmer Rietveld, Material in the Dutch Economy, a Vulnerability Analysis (Delft: TNO, 2015), 42.
} 


\subsection{New Issues in Well-being}

New issues in well-being, both 'here and now', 'later' and 'elsewhere' emerged in relation to the acquisition both of abundant mineral raw materials like gravel and sand as well as scarce materials like molybdenum and indium. Questions concerning trade-offs among economy, environment, and spatial planning; on the displacement of problems from the Netherlands to abroad; on the dependence of Europe on the rest of the world. But also questions about the responsibility of private enterprise and governments. Where did these begin and end? And in addition, also questions about scale. What scale was best suited to taking action in a world of global flows of trade? And finally questions about initiative and engagement: where did initiative lie in a manifold 'multi-polar' world?

Finding a balance proved to be the big challenge and was at times no sinecure. For example in 2013, the Foundation 'The Green Accountancy Chamber' - a critical follower of Dutch environmental policy - issued a report on Neodymium. This material was used in the permanent magnets of windmills. In the course of extracting this rare earth metal in Baotou in China, radioactive and poisonous by-products were deposited in a lake measuring $120 \mathrm{~km}^{2}$.

This is the deadly and sinister side of the windmill manufacturers that we don't like to be reminded of. ${ }^{38}$

The report became popular above all under critics of wind energy. The VVD (the right-wing People's Party for Freedom and Democracy) asked questions about Baotou in parliament. Minister of Economic Affairs, Kamp, (also VVD) shared the concerns about people and the environment. He also offered China assistance via the Special Emissary in combatting the harmful side-effects, but no further steps were taken. ${ }^{39}$ In the provincial estates of North Holland, North Brabant and Gelderland the PVV (ultra-right populist Party for Freedom) got this issue on the agenda. In Gelderland in 2014 a proposal was submitted to ban the use of Neodymium in windmills. After legal evaluation, the proposal was withdrawn by the provincial government in $2015 .^{40}$

\footnotetext{
${ }^{38}$ Windenergie in Nederland, de Dodelijke Keerzijde van Windenergie (Apeldoorn: De Groene Rekenkamer, 2013).

${ }^{39}$ Tweede Kamer der Staten Generaal, Aanhangsel van de Handelingen, vergaderjaar 2013-2014, 'Vragen gesteld door de leden der Kamer, met daarop door de regering gegeven antwoorden' no 1031

${ }^{40}$ Besluitenlijst GS Gelderland 10 februari 2015, nr 3 (2014-002183) 'Beleid over gebruik Neodymium in windmolens' (http://applicaties.gelderland.nl/asp2008/besluitenlijst/c-lijst. asp?AgendaID=789).
} 


\section{Literature}

Anonymous, (1989a, 19 January). 'Eigen cementindustrie in open Europa niet nodig', in Limburgs Dagblad, $\mathrm{p} 21$.

Anonymous, (1989b, 19 January). 'Milieu wint het van economisch belang bij verbod tot afgraven mergelplateau' in NRC Handelsblad.

Bastein, Ton, and Elmer Rietveld. (2015). Material in the Dutch Economy, a Vunarebilty Analysis. Delft: TNO.

Bol, Derk, and Ton Bastein. (2012). Critical Materials and the Netherlands - a View from the Industrial-Technpological Sector. Delft: M2i Materials Innovations Institute/TNO.

Bosch, A., and W. van der Ham. (2015). Twee Eeuwen, Rijkswaterstaat 1798-2015. 2e druk. Asten: Nieuwe Uitgevers.

Buijs, Arjen, Thomas Matthijssen, and Bas Arts. (2014). "“The Man, the Administration and the Counter-Discourse': An Analysis of the Sudden Turn in Dutch Nature Conservation Polict." in Land Use Policy 38: 676-84.

Cammen, H. van der, and L.A. de Klerk. (1999). Ruimtelijke Ordening, van Plannen Komen Plannen, de Ontwikkelingsgang van de Ruimtelijke Ordening in Nederland. 4e ed. Utrecht: Het Spectrum.

Cramer, Jacqueline. (2014). Milieu. Elementaire Deeltjes 16. Amsterdam: Amsterdam University Press.

CBS, (2010a). Critical Materials in the Dutch Economy, Preliminary Results. The Hague/Heerlan: CBS Center for Policy Related Statistics.

CBS, (2010b). Critical Raw Materials for the EU, Report of the Ad-Hoc Working Group on Defining Critical Raw Materials. Brussels: European Commission, Enterprise and Industry, 2010.

Disco, Nil, and Frank Veraart. (2016). 'A Farewell to Big Planning? 1990-2010.' In Builders and Planners, a History of Land-Use and Infrastructure Planning in the Netherlands, edited by Jos Arts, Ruud Filarski, Hans Jeekel, and Bert Toussaint, 351-437. Delft: Eburon.

Eikelboom, R.T., E. Ruwiel, and J.J.J.M. Gouwmans. (2001). 'The Building Material Decree: An Example of a Dutch Regulation Based on the Potental Impact of Materials on the Environment.' in Waste Management 21: 295-302.

"ENCI's Struggle for the Margaten Plateau, a Clash of Economical and Environmantel Interests." Universiteit Maastricht (Faculteit Cultuurwetenschappen) Bachelorscriptie, December 6, 2009. www.oudsintpieter.com/Presentaties.htm.

Grondelle, G.W. (1978). Ontgrondingen, over de Noodzaak En Mogelijkheden Voor Een Ander Beleid T.a.v. de Winning van Mergel, Grind, Zand, Klei, Veen, Enz., 's Gravenland: Stichting Natuur en Milieu.

Henckens, Theo. (2016). Managing Raw Materials Scarsity, Safeguarding the Availability of Geological Scares Mineral Resources for Future Generations. Universiteit Utrecht.

Hofstra, U., B. van Bree, R. de Wildt, and J. Neele. (2006). Scenariostudie BSA-Granulaten, Aanbod En Afzet van 2005 Tot 2025. Sittard: INTRON / Expertisecentrum Bouwstoffen Rijkswaterstaat.

Ike, Paul. (2000). De Planning van Ontgrondingen. Rijksuniversiteit Groningen, Geo Pers.

Korteweg, Rem. (2011). Op Weg Naar Een Grondstoffenstrategie, Quick Scan Ten Behoeve van de Gronstoffennotitie. The Hague: The Hague Centre for Stratagic Studies/TNO/CE Delft.

Meulen, M.J. van der, T.P.F. Koopmans, and H.S. Pietersen. (2003). 'Construction Raw Materials Policy and Supply Practices in Northwestern Europe'. in Aardrijkskundige Mededelingen, Industrial Minerals - Resources, Characteristics and Applications., 13: 19-30.

Meyer, Han. (2016). De Staat van de Delta, Waterwerken, Stadsontwikkeling En Natievorming in Nederland. Nijmegen: Van Tilt.

Mulder, Evert. (2008). Kringbouw, Naar Een Duurzame Grondstoffenvoorziening in de Bouw. Apeldoorn: TNO Industrie en techniek. 
Rode, Thomas. (2010). 'Een Wereld van Cement? De Strijd Om Het Plateau van Margraten, 19761989.' in Studies over de Sociaal-Economische Geschiedenis van Limburg 55: 26-48.

Sigmond, G.J.A., A.A. Veerbeek, F. Fokke, D.J.van Herwaarden, L.S.de Jonge, and J.A.J. Kemps. (1984). 1974-1984, Tien Jaar: Industrie En Ontgrondingen. FODI, De Steeg.

"The Raw Materials Initiative - Meeting Our Critical Needs for Growth and Jobs in Europe." Communications from the Commission to the European Parliament and Council COM (2008) 699. Brussels: Commission of the European Communities, April 11, 2008.

Tommel, D.K.J., G. Blom, and M.A. van Weel, eds. (2009, 17 December). Slotadvies van de Commissie Taakstellingen En Flankerende Beleid Voor Beton- En Metselzandvoorziening. Ministerie van Verkeer en Waterstaat, Interprovinciaal Overleg (IPO).

"Windenergie in Nederland, de Dodelijke Keerzijde van Windenergie." Apeldoorn: De Groene Rekenkamer, 2013.

Zon, Henk van. (2002). Geschiedenis En Duurzame Ontwikkeling, Duurzame Ontwikkeling in Historisch Perspectief, Enkele Verkenningen. Vakreview. Nijmegen: Universitair Centrum Milieuwetenschappen.

Open Access This chapter is licensed under the terms of the Creative Commons Attribution 4.0 International License (http://creativecommons.org/licenses/by/4.0/), which permits use, sharing, adaptation, distribution and reproduction in any medium or format, as long as you give appropriate credit to the original author(s) and the source, provide a link to the Creative Commons license and indicate if changes were made.

The images or other third party material in this chapter are included in the chapter's Creative Commons license, unless indicated otherwise in a credit line to the material. If material is not included in the chapter's Creative Commons license and your intended use is not permitted by statutory regulation or exceeds the permitted use, you will need to obtain permission directly from the copyright holder. 